JPPUMA: Jurnal Ilmu Pemerintahan dan Sosial Politik UMA Uournal of Governance and Political Social UMA), 8 (2) (2020): 106-111, DOI: https://doi.org/10.31289/ippuma.v8i2.3563

JPPUMA: Jurnal Ilmu Pemerintahan dan Sosial Politik UMA (Journal of Governance and Political Social UMA)

Available online http://ojs.uma.ac.id/index.php/ippuma

\title{
Reconsidering the Closed Proportional System for Indonesia
}

\section{Rahani Itsia Kurnianingrum *}

Election Governance Concentration, Masters Program in Political Science, Faculty of Social and Political Sciences, Universitas Airlangga, Indonesia

Received: March 08, 2018; Reviewed: April 19, 2020; Accepted: May 12, 2020

\begin{abstract}
This paper explains how the application of an open proportional system and a closed proportional system in the legislative elections in Indonesia. The problem is focused on how the consequences of implementing an open proportional system compared to closed proportionality after the widespread discourse to return to a closed proportional system. Moreover, a number of problems emerged after the 2019 simultaneous elections were carried out in an open proportional system. The open proportional system was considered more complicated for voters and for election administrators. Meanwhile, for election participants, an open proportional system created internal conflicts in political parties. The data in this paper were collected through literature study and analyzed qualitatively. This study concludes that a closed proportional system was considered to be more efficient in the process of casting and printing the ballots. The closed proportional system was also simple for voters, because voters only chose images of political parties. On the other hand, political parties as election participants must also improve their party system to be more democratic so that the cadres of the best political parties who side with the people have the same opportunity to compete in the election. Ease of voters and the quality of election participants are important because the essence of elections is participation and contestation.

Keywords: Election; Proportional Closed; Proportional Open.
\end{abstract}

How to Cite: Kurnianingrum, R.I. (2020). Reconsidering the Closed Proportional System for Indonesia. JPPUMA: Journal of Governance and Political Social Sciences UMA Uournal of Governance and Political Social UMA), 8(2): 106-111

${ }^{*}$ Corresponding author:

ISSN 2549-1660 (Print)

E-mail: hani.itsia2@gmail.com

ISSN 2550-1305 (Online) 


\section{INTRODUCTION}

In a democratic country, General Election is a measure of the success of a country in democracy, where the more democratic process of implementing elections in a country indicates that democratic life in that country has been already running well. Democracy is characterized by three prerequisites, firstly competition in competing for and maintaining power, secondly public participation and thirdly, the guarantee of civil and political rights. Through this election system, the competition, participation and guarantee of political rights can be seen (Marijan, 2010). In this way, it is expected that a harmonious government can be created with stable political conditions and is also accompanied by legal certainty so that it can support high economic growth for a democratic country. Therefore, every democratic country attempts to look for the most suitable general election system for their own country.

The general election system is important for several reasons. First, there is a perception that it will have an impact on the level of coherence of the party system, and ultimately on the effectiveness of government. The general election system can also help alleviate or exacerbate political conflicts. In addition, whether the general election system helps to form the public policy outcomes and the behavior and incentive structures of political actors or not. Whether politicians depend directly on voters or on their parties to advance their careers is based on an electoral formula in determining who they feel most responsible. It will affect to what they might strive for from public resources to build relationships with their voters, and for the sake of contestation whether it will lead to election corruption and malpractice. (Menocal, 2011). In his speech, Ramlan Surbakti said that the Election system is a set of procedures for converting voters' votes into seats. The Election system has several elements including (1) the size of the electoral district, (2) participants and nomination patterns, (3) voting model and (4) formula for selecting and determining elected candidates. These four elements absolutely must be present in the Election system. The next elements are (5) electoral threshold and (6) election calendar, which exist because of the objectives to be achieved, for example the electoral threshold serves to reduce the number of parties in parliament (Surbakti, 2016) (3) voting model and (4) formula for selecting and determining the elected candidates. These four elements absolutely must be present in the Election system. The next elements are (5) the electoral threshold and (6) the election calendar, which exist because of the objectives to be achieved, for example the electoral threshold which has function to reduce the number of parties in parliament (Surbakti, 2016).

There are many models of general election systems in the world. These variations can be grouped into the three broad families of the Election system. Based on the electoral formula, there are three models of the electoral system, namely the majority / plurality system, the proportional system and the mixed system (Reynold et al, 2005).

First, the majority / plurality system known in Indonesia by the district system. The majority system cannot represent the voices of minorities and diversity in Indonesia. In the majority system, the winner takes all, so that a lot of votes will be wasted. The second is the proportional election system. This system has two variations, namely the open proportional system and the closed proportional system. Although there is another variation of the open proportional system, namely Single Transferable Vote (STV), where voters provide the serial number of candidates in multiple-member constituencies and is another very well-established proportional system. In the context of Indonesia, the STV system is still not applicable because of the 
low political literacy of voters, which makes it difficult for voters. The third is a mixed system where this system combines the benefits of the majority system / plurality with a proportional system. Because of this merger, the implementation of the mixed system becomes complex.

Of course there is no perfect electoral system, because each has advantages and disadvantages so that an ideal election system in one country will not necessarily be suitable for other countries. There are several things that underlie why a country chooses an electoral system, for example, is it a federal state or a unitary state? Is it a presidential or parliamentary system? Likewise with the voters, is the level of political literacy well established? Has the democratic climate been established or not?

Indonesia has held elections since the independence era. Through these Elections, efforts are made to find out what kind of Election system is suitable to be applied in Indonesia. Indonesia country is an adherent of the representative proportional election system. It is because the number of participants in every election takes place tends to be large. In this system, the allocation of the number of seats in representative institutions was carried out proportionally based on the votes acquired by each election participant. The allocation and distribution of seats is based on the population.

The 2019 election was Indonesia's first simultaneous election. In addition, there was an increase in the number of electoral districts compared to the 2014 Election. For the 2019 Election, the General Election Commission had determined 80 electoral districts throughout Indonesia for members of the Indonesian Parliament compared to only 77 electoral districts in the 2014 elections (Wiwoho, 2018). The number of members of the People's Representative Council for the 2019-2024 period has become 575, more than 560 members of the People's Representative Council in the 20142019 period. The number of seats increased because there was an increase in the number of residents based on the aggregate population list per district (DAK2). In addition, there are 17 new autonomous regions resulting from regional expansion. (ANTARA, 2019). The number of seats for Provincial Regional People's Representative Council members also increased from the previous 2,112 seats to 2,207 seats in the 2019 Election. Likewise, the seats for Regency / City People's Representative Council seats from 16,896 became 17. 610 seats. (Akbar, 2018)

From the implementation of the General Election in Indonesia, it can be concluded that several things have become facts, including the General Election in Indonesia which is the largest General Election in the world which is held in one day. It is so called because with the total number of voters of 192,828,520 in the 2019 simultaneous elections, both at home and abroad, the voting and counting processes were carried out in one day. In comparison to India which also holds the largest Election in the world but voting is held in about a month and is held alternately in various states. It is a definitely democratic party that demands strong mental and physical endurance from the election organizers, especially the Voting Organizing Group (KPPS) as the front guard. However, the process of voting and counting votes at the polling stations (TPS) is considered the best practice in the world. (Supriyanto, 2020).

It is stated to be the best practice because: first, during voting, the principles of direct, general, free, confidentiality was materialized. Second, the principle of transparency was implemented during vote counting because it was jointly witnessed and counted, there was no gap for manipulation. Third, the recapitulation process is the longest in the world because it has to be do in stages and manually from polling stations to district / city for People's Representative Council in Regency / City, to provincial for Provincial People's Representative Council and up to the center 
for People's Representative Council and Regional People's Representative Council.

This simultaneous election was a complicated election throughout history with records of victims from the organizers, namely Voting Organizing Group who died as many as 469 people. It was suspected because many Voting Organizing Group officers were tired with very high workloads. There were 2 pairs of presidential and vice presidential candidates, 16 national political parties and 4 Aceh local parties at the People's Representative Council, Provincial Regional People's Representative Council, Regency/City Regional People's Representative Council and Regional Representative Council levels which must be collected and counted at the Polling station level in a short time so that it is impossible to take rest and stop (Harahap, 2019).

Currently in Indonesian politics, there is a discourse to return the open proportional system back to the closed proportional system. Among those who provided this discourse was the Association for Elections and Democracy (Perludem). In this paper, it is examined the consequences of implementing an open proportional system compared to a closed proportional system after the implementation of the 2019 Election. Therefore, the rational considerations can be obtained in determining an election system that can be used sustainably and not interchangeably.

\section{RESEARCH METHOD}

Based on the problems to be studied, the data in this paper were collected from books, literature, research results, Election Governance lecture discussions and direct observations of the author in the field as election administrators. The author is looking for as much information as possible on the topic of writing including from other sources such as the internet. According to Sugiyono (2012), literature studies are closely related to values, culture and norms that develop in the social situation which were studied by theoretical studies and other references.

The stage of this paper was to find the problem of topic and then collect data from various relevant sources. After the data were collected, it was analyzed using a qualitative approach and compiled into a writing.

\section{RESULTS AND DISCUSSION Closed Proportional System}

In Indonesia, the General Election has been held since 1955, and the Indonesian Election system has changed from a closed proportional Election system, to an open proportional election system that has been implemented in the 2004, 2009, 2014 Elections and in 2019. Due to the fourth amendment of the 1945 Constitution in 2002, the previous elections were only used to elect members of legislative institutions such as the People's Representative Council (DPR), the Provincial Regional Representatives Council (DPRD), and the Regional People's Representative Council (DPRD) districts / cities, and now are also used to elect the president and vice president with the terms and conditions stipulated in the Election Law. In addition, the General Election can also be used for regional head elections both at the provincial level, namely the governor and also at the district and city levels, namely regents and mayors, it is in accordance with Law Number 22 of 2007 concerning General Election Administrators up to the 2014 Election.

After the issuance of the Decision of the Constitutional Court (MK) Number 14 / PUU-XI / 2013, the implementation of Presidential Election was carried out simultaneously with the Legislative Election which its implementation is regulated in book 1 (one ) of laws since 2017. While the Local Election or Regional Head Election (Pilkada) ) was carried out based on the schedule of the respective regional head elections because the Constitutional Court's decision considers that Regional Head 
Election is not a general election, so it is regulated in a separate law book.

Meanwhile, political conditions, regional conditions, and cultural conditions of a country really determine the Election system which is suitable for use in the General Election process in a democratic country. Indonesia is a developing country where the level of education and welfare of the population is still not evenly high. It is an important element in establishing an Election system to make it easier for voters to vote. Based on the data from the Central Statistics Agency, there are still six provinces in Indonesia with illiteracy rates of more than four percent in 2018, namely West Kalimantan (4.21\%), South Sulawesi (4.63\%), West Sulawesi (4.64\%), East Nusa Tenggara (5.24\%), West Nusa Tenggara (7.51\%) and Papua (22.88\%). (Antara, 2019).

Based on the characteristics possessed by Indonesian country which has many ethnic groups, many islands, several religions, the level of education and uneven welfare of the society and there are still many who are not technologically literate, especially the internet, so the suitable Election system for Indonesia is a system Proportional election. It is due to every vote was counted so that no vote was wasted and small parties and minorities had the opportunity to send their representatives in parliament. Of course it was very representative of the diverse society in Indonesia.

A closed proportional system was a system where voters only cast a party image on the ballot. Furthermore, the elected candidates were determined internally based on the serial number set by the political party. The closed proportional system ensured that the public chose sufficiently the party and political parties sent the best cadres based on their assumption to parliament. With the assumption that it was the party that knew which cadres had the best capabilities as representatives of the people. It can revive the function of political parties as election participants, namely preparing cadres to occupy leadership positions in the parliament so that they were expected to be able to push the representative people in a better direction.

The closed proportional system required less costed than the open proportional system because first ballots were printed uniformly throughout Indonesia so that they costed less than ballots in an open proportional system where ballots for each region were different because there were different names of candidates, secondly, campaign costs would be cheaper because the campaign of political parties in all regions was same and only the campaign of political parties. Meanwhile, in open proportions, each candidate would compete to campaign which of course the campaign costs would be more expensive because the campaign props (APK) were each issued by the legislative candidates.

From a voter perspective, using a closed proportional system also made it easier for the voters to understand ballots and cast their votes. It was since the ballots were not too wide so it was easy to open and fold them back. Ballot papers only contain pictures of political parties and choosing pictures will be easier for voters than reading the list of names of legislative candidates from each political party, especially for non-literate and elderly voters. If voters did not vote too long, of course, it would reduce the queue time at polling stations (TPS) so that it fulfilled the element of voter convenience. Convenience in the form of ease of casting votes would increase the voter turnout and can reduce the number of invalid votes.

The closed proportional system was also simpler and easier in terms of implementation of the elections. In the calculation, the logistics arrangement and distribution was clearly easier for the General Election Commission (KPU), especially easier for the adhoc organizer at the Polling Station level, namely Voting 
Organizing Group, because the ballots were same so that there was no distinction in each electoral district. In the recapitulation it was also easier because it only counted the pictures of political parties chosen by voters without counting the names of each legislative candidate. Therefore by this closed proportional election system, it can be stated that it was far more economical because the results of the printing of ballots were same at almost all election levels, both at the central and regional levels, so that it coukd save costs and time in the Election process starting from printing ballots to counting voting results.

However many people thought that using a closed proportional system means to return to the Election model during the New Order Era. It is since this system has several weaknesses, namely distancing access to relations between constituents or voters and representatives of the people after the election and narrowing the space for public participation in the Election. The voters cannot directly elected representatives according to their preferences. The closed proportional system also makes political communication ineffective. Because everything became the decision of a political party, a crisis for legislative candidates could also occur because there were only a few who were interested and serious in advancing to become legislative candidates. The party, of course, has full power and determines which cadres will sit in the parliament (Republika, 2019). However, in national elections where voters vote for a closed party list, party leaders had a great power as they determine the rank of each candidate on that list. With such systems, parliamentarians tend to feel more accountable to party leadership than to voters, their political future rests with the party rather than with the voters. (Effendi, 2016).

\section{Open Proportional System}

The 2004 General Elections began to be implemented with a different system from the previous General Elections. Elections to elect members of People's Representative Council and Provincial Regional People's Representative Council as well as Regency / Municipal People's Representative Council were conducted using an open proportional system. The valid votes a Political Party got will determine the number of seats obtained. Then the seat quota obtained would be given to candidates who meet or exceed the majority value. Unless, then a seat will be given to the candidate based on the serial number. Meanwhile, the Election for Regional People Representative Council members was carried out with a multi-representative district system.

The open list system of candidates or also known as the open proportional system has been used until the 2019 elections. In an open proportional system, the people are considered to be fully sovereign. This system also guaranteed and ensured that the voice of the people determined who sat in parliament. The open proportional system had a candidate center voting model, where voters directly elect legislative candidates who according to voters would represent them in parliament and the elected candidates were determined based on the most votes. Therefore in the ballot there is not only a picture of a political party but also the name of the candidate proposed by the party according to the serial number, provided that 30 percent must reflect women's representation (Law Number 7 of 2017).

The open proportional system provided equal opportunities for all legislative candidates even though they had different serial numbers and financial capacities, to be entitled to occupy parliament (Halim, 2014). In an open proportional system, because voters knew the names of the people's representatives they would elect, it can lead to a closer relationship between the voters and the elected people's representatives. The voters who had close feeling can increase their 
participation and control over the representative. In addition, party electability could also increase due to the high popularity of the legislative candidates in society, which can lead to a more dynamic internal party. Thus, it can be said that with an open proportional system, the diversity of society can be facilitated. However, this system also provided weaknesses where the internal party competition would occur between cadres which can reduce party control. This system reduced the role of the party, as well as created contestations between cadres within the party and hinders party ideological cadres (Supriyadi, 2017).

In an open proportional system, it could cause the cadres competed with each other for the influence of voters by all means so that unhealthy contestations could occur both internally and externally. It is due to basically these candidates competed with candidates in the same electoral district and in the same political party. Each candidate competed to win the votes of the people with the biggest possible campaign which of course required large funds and can also encouraged the buying and selling of voters' votes in order to get seats. In addition, the high political costs that must be incurred by each cadre will cause rampant corruption when they become People's Representative Council. Thus, this system could create a potential conflict, where cadres who later become members of parliament would prioritize their own interests over the interests of the people, and could also reduce the role of political parties in the legislature. The injustice in the process of regenerating political parties would also be seen because the instant cadres such as public figures or artists who run for political party vehicles will be easily recognized by voters without considering their political journey in the political party. Of course it would get rid of old political party cadres who had served as administrators and cadres in raising the party. But on the other hand, political party infrastructure would be more vibrant because internal party dynamics tend to be dynamic. The popular candidates would certainly be able to increase the electability of the political party (Jamil, 2016).

In an open list proportional system with the determination of elected candidates based on the principle of majority votes, political parties were not the only main actors controlling campaign funds. Thus if an open list proportional system was chosen, the provisions on campaign funds should stipulate that each legislative candidate had the responsibility to report campaign funds in an integrated manner with the campaign fund reports of political parties. The reporting must be periodic. The law should also provide for administrative sanctions. If candidates for People's Representative Council and Regional People's Representative Council members did not report campaign funds to be integrated into the political party's campaign fund reports, the General Election Commission must subject the administrative sanctions in the form of cancellation of his / her candidacy at the recommendation of a political party (Pramono, 2012).

Campaign finance reporting was important because it was to regulate the contestation to run equally and ensure that the candidates did not get a source of campaign fund contributions only from a certain person or group. If it happened, it would make the candidates who would be representatives in the parliament not responsible to the voters or the public but to the contributors. It would be better for the candidates to receive contributions that are not too large but come from various people.

The open proportional system was considered ideal for Indonesia because public aspirations were not such pig in a poke. However the open proportional election system that has been implemented since the 2009 elections was an election system that is difficult to understand for ordinary voters because it was very complex in the world. In fact, the Election system should be simple, that is, simple to understand by all elements of voters and 
simple to be implemented by election organizers and election participants. (Pahlevi, 2015).

\section{CONCLUSION}

The design of an effective and sustainable general election system would be easier for voters and politicians to understand. Too many complications could lead to misunderstanding, undesirable consequences and voter distrust of the election results including the death of hundreds of Voting Organizing Group such as in the 2019 simultaneous elections. If should be back to closed proportional system it was better accompanied by increasing the party system to be more democratic. The process of recruiting candidates was a very important factor in winning competitions during elections. Political parties should recruit candidates in a transparent and opened and make clear rules so that the conflicts did not occur during campaign implementation and the determination of elected candidates. It could be done through internal elections or such open convention that allowed every member of a political party to be involved in the nominating mechanism. The recruitment of legislative candidates should be carried out by considering man's political capacity and ability so that the elected man was able to guard the party's political agenda maximally. Political parties should provide political education to the constituents and the voters, so that the political literacy increases and votes trading would decrease so that the election results will be high quality (Mahmud, 2018). A party should be able to become an institution for its members so that the members of a party did not move to another party easily and become instant legislative candidates whose competence as a politician had not been tested.

Another important thing was the Election system should aim to strengthen the democracy so that it must increase the voter participation. In a democracy it was better if the voter participation was higher. Thus the degree of voter participation is equally important compared to the degree of representation. A simple, well-established and sustainable general election system would have a positive impact on many aspects. The general election system and regulations that did not often change would guarantee legal certainty in implementation of elections. Voters were also not confused by the voting mechanism which changes frequently, thus avoiding to participate in the Election. The voter's education background was also not just fixated on the voting and counting process but also could affect many things in the General Election that then would increase the political literacy of voters. In terms of implementation, a sustainable Election system facilitated the budget and program planning process, because the Election stages did not change and restarted from zero so that they could focus more on fixing the deficiencies in the previous Election, which of course would save a lot of budget. Because of the well-established election system, political parties were expected to be more focused on struggling the public agenda through their representatives in parliament. The Election System was not only a matter of efficiency in its implementation, but the democratic factor or not the Election resulting from the Election system was more important.

\section{REFERENCES}

Akbar, C. (2018). KPU: Ada Penambahan Kursi Anggota DPR dan DPRD Pada 2019. Diunduh di https://nasional.tempo.co/read/1080992/kp u-ada-penambahan-kursi-anggota-dpr-dandprd-pada-2019 tanggal 08 Februari 2020.

Antara. (2019). 575 Anggota DPR Dilantik Hari Ini, Berikut Data dan Faktanya, diunduh di https://www.beritasatu.com/nasional/5776 60/575-anggota-dpr-dilantik-hari-iniberikut-data-dan-faktanya tanggal 08 Februari 2020.

Antara. (2019). Mendikbud Sebut Angka Buta Huruf Di Indonesia Timur Masih Tinggi, diunduh di https://nasional.tempo.co/read/12448458/ mendikbud-sebut-angka-buta-huruf-diindonesia-timur-masih-tinggi tanggal 07 Februari 2020. 
Rahani Itsia Kurnianingrum, Reconsidering the Closed Proportional System for Indonesia

Effendi, A. (2016). Studi Komparatif Pengaturan Sisitem Pemilu Anggota DPR Di Indonesia. Jurnal Fiat Justisia, 10(2).

Halim, A. (2014). Dampak Sistem Proporsional Terbuka Terhadap Perilaku Politik (Studi Kasus Masyarakat Sumenep Madura Dalam Pemilihan Legislatif 2014). Jurnal Humanity, 9(2).

Harahap, R.A.F \& Fahmi, K. (2019). Analisis UndangUndang Nomor 7 Tahun 2017 Tentang Pemilihan Umum. JPPUMA: Jurnal Ilmu Pemerintahan dan Sosial Politik UMA (Journal of Governance and Political Social UMA). 7(2): 93-101.

Jamil, A. (2016), Ini Plus Minus Dengan Sistem Proporsional Tertutup. Diunduh di https://m.republika.co.id/berita/oaqz26354 /ini-plus-minus-pemilu-dengan-sistemprporsional-tertutup tanggal 09 Februari 2020.

Mahmud, I. (2018). Strategi Pemenangan Partai Keadilan dan Persatuan Indonesia (PKPI) dan Partai Keadilan Sejahtera (PKS) Dalam Pemilu Legislatif Kota Salatiga Tahun 2009. Jurnal Politika, 9(1).

Marijan, K. (2010). Sistem Politik Indonesia: Konsolidasi Demokrasi Pasca-Orde Baru. Jakarta: Kencana.

Menocal, R (2011), Why Electoral System Matter: An Analysis Of Their Incentives And Effects On Key Areas of Goverment. London: Overseas Development Institute (ODI).

Pahlevi, I. (2015) . Sistem Pemilu Di Indonesia Antara Proporsional dan Mayoritarian, Jakarta: P3DI.

Pramono, S. (2012) Menimbang Konsekuensi Pilihan Sistem Pemilu. Diunduh di https://amp.kompas.com/tekno/read/2012/ 03/20/05154820/menimbang.konsekuensi.p ilihan.sistem.pemilu tanggal 08 Februari 2020.

Reynolds, A, B. Reily \& A. Ellis. (2006). Desain Sistem Pemilu: Buku Panduan Baru International IDEA, Stockholm: International IDEA.

Republik Indonesia. (2017). Undang-Undang Nomor 7 Tahun 2017 Tentang Pemilihan Umum. Lembaran Negara RI Tahun 2017, No. 182. Sekretariat Negara. Jakarta.

Sugiyono. (2012). Metode Penelitian Kuantitatif Kualitatif dan R\&D. Bandung: Alfabeta.

Supriyadi, E. (2017). Ini Kelebihan dan Kekurangan Sistem Proporsional Terbuka. Diunduh di https://m.republika.co.id/berita/0jyvqu354/ ini-kelebihan-dan-kekurangan-sistemproporsional-terbuka tanggal 09 Februari 2020.

Surbakti, R. (2016). Pidato Inagurasi Anggota Baru Akademi Ilmu Pengetahuan Indonesia (AIPI) pada 20 November 2016. Tidak diterbitkan. Surabaya: FISIP Universitas Airlangga

Supriyanto, D. (2020). Pemilu dan Teknologi (3habis): Kerugian E-Voting, Keuntungan ERekap diunduh di https://m.detik.com/news/kolom/d4843615/pemilu-dan-teknologi-3-habiskerugian-e-voting-keuntungan-e-recap 24 Februari 2020.

Wiwoho, B. (2018). KPU Tetapkan Jumlah Dapil dan Kursi Pemilu 2019. https://m.cnnIndonesia.com/nasional/2018 0418181605-32-291797/kpu-tetapkanjumlah-dapil-dan-kursi-pemilu-2019 diunduh tanggal 08 Februari 2020. 